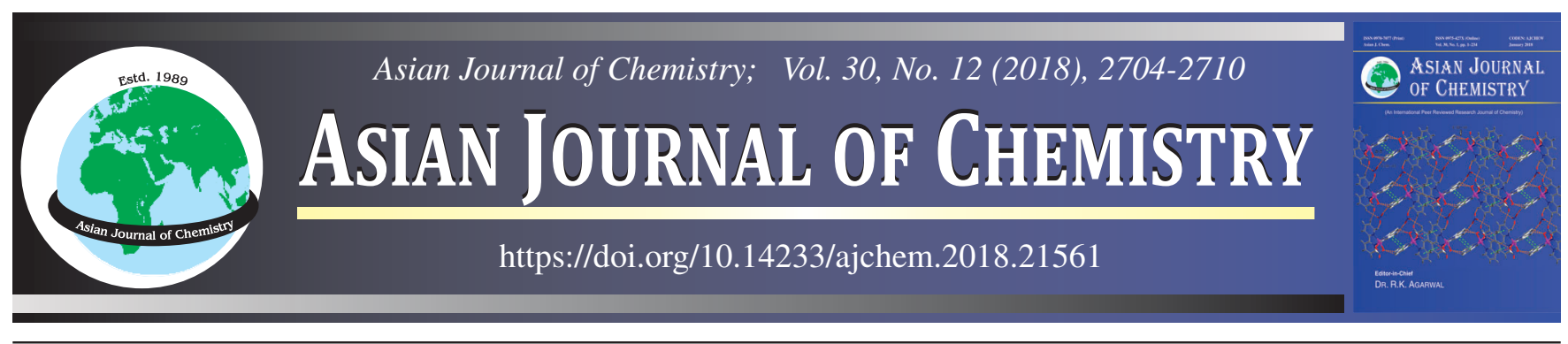

\title{
Chemometric Assisted Method Development for Teneligliptin and Metformin by Stability Indicating RP-HPLC Technique and its Validation
}

\section{Dasari Vasavi Devi ${ }^{1, *}$, Dugasani Swarnalatha² and Gopireddy Venkatasubba Reddy ${ }^{3}$}

${ }^{1}$ Department of Pharmaceutical Sciences, Jawaharlal Nehru Technological University Anantapur, Anantapur-515 002, India

${ }^{2}$ Annamacharya College of Pharmacy, Rajampeta-516 126, India

${ }^{3}$ Jawaharlal Nehru Technological University Anantapur College of Engineering, Pulivendula-516 390, India

*Corresponding author: E-mail: dvas.reddy@gmail.com

Received: 5 July 2018;

Accepted: 17 August 2018;

Published online: 31 October 2018;

AJC-19135

\begin{abstract}
An innovative quality by design approach is presented through the development of an RP-HPLC method for the analysis of antidiabetic drugs teneligliptin and metformin in its drug substance and drug products. Response surface optimization of the design experiments has been employed using quadratic central composite design (CCD) for the optimization of method parameters using reverse phase highperformance liquid chromatography (RP-HPLC) on Discovery C8, $250 \times 4.6 \mathrm{~mm}, 5 \mathrm{~m}$ with UV detection at $261 \mathrm{~nm}$. For the interaction and quadratic effects of three factors namely change in mobile phase ratio, flow rate and wavelength on the selected response using CCD model. This was applied to simultaneously optimize the retention time, peak area and tailing factor of teneligliptin and metformin. The predicted optimum assay condition consisted of buffer [0.1\% orthophosphoric acid (OPA) solution] and acetonitrile taken in the ratio $37: 63$ as mobile phase at a flow rate of $0.94 \mathrm{~mL} / \mathrm{min}$. Using this optimum condition, a retention time for metformin and teneligliptin were $3.086 \mathrm{~min}$ and $4.065 \mathrm{~min}$, respectively have been achieved. After establishing the optimal conditions for separation, validation parameters like linearity, accuracy, precision, LOD, LOQ and robustness have been determined which were based on ICH Q2 guidelines. Hence, the proposed method can be used for quality control of teneligliptin and metformin in its tablet dosage forms.
\end{abstract}

Keywords: RP-HPLC, Central composite design, Teneligliptin, Metformin.

ᄂ - - - - - - - - - - - - - - - - - - - - - - - - - - - - - - - - - -

\section{INTRODUCTION}

Quality of pharmaceutical products was considered as an important aspect by all regulatory bodies. The quality by design for the method development of the pharmaceuticals gives us more robust method. J.M. Juran, a well known quality expert developed the concept quality by design. Here, the appellant will plan the design space which had been undergoing regulatory analysis and consent [1-5]. International conference on harmonization in its Q8 pharmaceutical development, Q9 quality risk assessment and Q10 pharmaceutical quality system gives compelling conditions regarding quality of products. QbD basically aids to execute Q8 and Q9. Food and drug administration perspective of $\mathrm{QbD}$ is a systematic approach to product and process design and development [6-9]. QbD does not necessarily mean less analytical testing alternately, it means the right analysis at right time, and is based on science and risk assessment.
Pharmaceutical industries are adopting the concept of QbD, one can develop robust method which helps to follow ICH guidelines. Here components which enhance robustness are taken into consideration for the analytical method development in QbD environment. The method optimization was done using design expert software that follows a DOE approach [10]. Validation remains the formality as it is done in similar way to that of traditional method development in validation (ICH Q2) but in traditional method approach method validation after development i.e. it is like check box tool and in $\mathrm{QbD}$, the validation parameter in ICH Q2 are consider as method intent. Diabeties, are a group of metabolous disorders in which there are elevated blood sugar level over an extended duration [11]. It causes many complicated situations which includes cardiovascular disease, stroke, chronic kidney disease, foot ulcer and even damage to the eyes by causing diabetic retinopathy if left untreated [12]. As per International Diabetes Federation (IDF) in year 2015,

This is an open access journal, and articles are distributed under the terms of the Creative Commons Attribution-NonCommercial 4.0 International (CC BY-NC 4.0) License, which allows others to copy and redistribute the material in any medium or format, remix, transform, and build upon the material, as long as appropriate credit is given and the new creations are licensed under the identical terms. 
it was assessed that 415 million people had diabetes worldwide with type II Diabetics mellitus comprises of about $90 \%$ of the cases [13-15]. Hence, it is necessary to control diabetics by using various hypoglycemic agents. Gliptins are the novel class of compounds which reformed the treatment of diabetes during the recent past.

Teneligliptin is a new FDA approved long-acting, orally bioavailable, pyrrolidine based inhibitor of dipeptidylpeptidase-4 (DPP-4), with hypoglycemic activity used for the treatment of type II Diabetes mellitus [16-18]. For effective control of blood sugar level in diabetic patients more than one medication is required. Teneligliptin shows effective control of blood sugar when combined with metformin. Metformin hydrochloride is 1,1-dimethylbiguanide hydrochloride (N,N-dimethylimidodicarbonimidic diamide hydrochloride), a biguanide anti-diabetic [19]. An extensive literature review revealed that there are some analytical methods available in the literature for the estimation of teneligliptin such as UV spectrophotometry [20], HPLC [21,22], HPTLC [23] and metformin individually included in different pharmacopeias [24-28]. Moreover, many methods were reported for the estimation of metformin along with other drugs in combined formulation [29-37]. Analytical methods for the estimation of teneligliptin and metformin simultaneously are three different UV spectrophotometers [38], RP-HPLC methods [39-41]. There are few methods available in the literature for simultaneous estimation of teneligliptin and metformin in combined dosage form, but by applying statistical tools to the method development by RP-HPLC has not yet been reported by any method. Hence, this manuscript was the first to describe optimization of the method by chemometric design and validation of the developed method. The proposed method was simple, sensitive, stability indicating, accurate and more robust than the previous reported ones.

\section{EXPERIMENTAL}

Metformin and teneligliptin reference standards were procured as gift samples from MSN Pharmaceuticals, Hyderabad, India. Methanol, acetonitrile, orthophosphoric acid and water were of HPLC grade and purchased from Rankem Chemicals. The tablet formulation (Ten 20-M 500, composed of $20 \mathrm{mg}$ teneligliptin hydrobromide hydrate and $500 \mathrm{mg}$ extended release metformin hydrochloride) were procured from local market and used for analysis of drug product.

The chromatographic separation was carried out by Waters Acquity HPLC with binary solvent manager, equipped with Tunable UV detector and auto sampler. The Empower 2 software was used for signal monitoring, data collection and data processing. In addition, an electronic balance (BL-220H; Shimadzu Corporation), a pH meter (ELICO® LI 120), a sonicator (PCi, Mumbai) has been employed in this study. Isocratic separation was achieved on an STD Discovery C8 $(250 \times 4.6 \mathrm{~mm}, 5 \mu \mathrm{m})$ column.

Design-Expert 10.0.0.7 trail version (Stat-Ease Inc., USA) have been used for the experimental design, data analysis and desirability function calculations. The rest of the calculations for the analysis were performed with the help of Microsoft Excel 2007 software (Microsoft, USA).

Preparation of mobile phase and stock solutions: The mixture of $630 \mathrm{~mL}$ of acetonitrile and $370 \mathrm{~mL}$ of $0.1 \%$ orthophos- phoric acid buffer was taken and sonicated for $30 \mathrm{~min}$ and filtered through $0.45 \mu \mathrm{m}$ membrane filter and has been used as mobile phase. $0.1 \%$ orthophosphoric acid buffer was prepared by taking $1 \mathrm{~mL}$ of orthophosphoric acid solution in a $1000 \mathrm{~mL}$ of volumetric flask and added about $100 \mathrm{~mL}$ of HPLC grade water and final volume make up to $1000 \mathrm{~mL}$ with HPLC grade water.

Stock solutions were prepared by accurately weighing 50 $\mathrm{mg}$ and $2 \mathrm{mg}$ of metformin and teneligliptin working standards into a $10 \mathrm{~mL}$ clean dry volumetric flask. To this $7 \mathrm{~mL}$ of diluent were added; sonicate it for $30 \mathrm{~min}$ and make up to the final volume with the same diluent. The solutions were further diluted with the same diluent to obtain final concentrations of 500 and $20 \mu \mathrm{g} / \mathrm{mL}$ metformin and teneligliptin, respectively. Here, the diluents have been prepared by using $50 \mathrm{~mL}$ of acetonitrile and $50 \mathrm{~mL}$ of water, i.e., $1: 1$ ratio respectively.

Analysis of marketed formulation: About 20 tablets were weighed and calculate the average weight of each tablet then the weight equivalent to one tablet was transferred into a 50 $\mathrm{mL}$ volumetric flask, $30 \mathrm{~mL}$ of diluent added and sonicated for $30 \mathrm{~min}$, further the volume made up with diluent and filtered. The filtered solutions were further diluted with the same diluents used in the stock solution preparation to obtain final concentrations of 500 and $20 \mu \mathrm{g} / \mathrm{mL}$ metformin and teneligliptin, respectively. The above sample solution was injected into HPLC system and peak areas were measured under optimized chromatographic conditions.

Optimization of method assisted through software: After the initial screening of conditions like stationary phase, mobile phases, the method has been gone for optimization by using Design Expert 10 software. In this software, central composite design under the category of response surface methodology (RSM) have been employed to design a set of experimental runs by concerning the three independent variables i.e., flow rate, wavelength and acetonitrile ratio in the mobile phase. Here, the independent variables ranges were entered along with their actual levels (Table-1). In experimental design, central composite design was followed with three factors, 2 levels, 5 responses and 20 experimental runs. These three factors have an effect on the dependent variables i.e. retention time, resolution and peak area.

\begin{tabular}{cccc}
\multicolumn{4}{c}{ TABLE-1 } \\
\multicolumn{3}{c}{ VARIABLES SELECTED IN } \\
\multicolumn{1}{c}{ CENTRAL COMPOSITE DESIGN } \\
\hline \multirow{2}{*}{ Factors } & \multicolumn{3}{c}{ Levels used } \\
\cline { 2 - 4 } & Low (-1) & Medium (0) & High $(+1)$ \\
\hline Independent variables & & 1 & 1.1 \\
Flow rate (mL/min) & 0.9 & 40 & 45 \\
Mobile phase & 35 & 263 & 266 \\
Wavelength (nm) & 260 & & \\
Dependent variables & & 2.884 & 3.47 \\
t $\mathrm{R}_{\mathrm{R}}$-Met (min) & 2.478 & 4.030 & 4.905 \\
$\mathrm{t}_{\mathrm{R}}$-Ten (min) & 3.413 & 6065677 & $1.48437 \times 10^{6}$ \\
Area-Met & $2.10054 \times 10^{6}$ & 386382 & 562896 \\
Area-Ten & 220531 & 7.3 & 12.2 \\
Resolution & 3.8 & & \\
\hline
\end{tabular}

Chromatographic conditions: The final conditions optimized by the software include $0.942 \mathrm{~mL} / \mathrm{min}$. flow rate, 261.08 $\mathrm{nm}$ of wavelength and $37 \%$ of acetonitrile ratio in the mobile 
phase. The HPLC analysis was performed on reverse phase high performance liquid chromatographic systems with isocratic elution mode using a mobile phase of acetonitrile and buffer (63:37, v/v) on STD dis 250 C8 column $(250 \times 4.6 \mathrm{~mm}, 5 \mu \mathrm{m}$ particle size) with flow rate $0.94 \mathrm{~mL} / \mathrm{min}$ at $261.08 \mathrm{~nm}$ using TUV detector. The column temperature has been maintained at $30^{\circ} \mathrm{C}$ with an injection volume $10 \mu \mathrm{L}$. The comparison of initial HPLC method and optimized HPLC method from design expert experiments are drawn in Table-2.

\section{TABLE-2}

A COMPARISON OF INITIAL HPLC METHOD, OPTIMIZED

HPLC METHOD FROM DESIGN EXPERT EXPERIMENTS

\begin{tabular}{lcc}
\hline \multicolumn{1}{c}{ Parameter } & Initial method & Optimized method \\
\hline Column & Discovery $250 \times$ & Discovery $250 \times$ \\
& $4.6 \mathrm{~mm}, 5$ & $4.6 \mathrm{~mm}, 5$ \\
Injection volume $(\mu \mathrm{L})$ & 10 & 10 \\
Column temp. $\left({ }^{\circ} \mathrm{C}\right)$ & 30 & 30 \\
Flow rate $(\mathrm{mL} / \mathrm{min})$ & 1 & 0.94 \\
Detection $(\mathrm{nm})$ & 263 & 261 \\
Mobile phase & $40: 60$ & $37: 63$ \\
Run time $(\mathrm{min})$ & 6 & 6 \\
\hline
\end{tabular}

Sample preparation for stability studies: In developed method stability is indicating both the drugs were stressed under various conditions like acid, alkaline and neutral hydrolysis and peroxide to perform forced degradation studies [42-45].

Acid induced degradation: Stock solution of metformin and teneligliptin ( $1 \mathrm{~mL}$ each), $1 \mathrm{~mL}$ of $2 \mathrm{~N} \mathrm{HCl}$ was added and refluxed for $30 \mathrm{~min}$ at $60^{\circ} \mathrm{C}$. The resultant solution was diluted to obtain 500 and $20 \mu \mathrm{g} / \mathrm{mL}$ solution and $10 \mu \mathrm{L}$ solutions were injected into the system and the chromatograms were recorded to assess the stability of the sample.

Alkaline induced degradation: It was performed by taking $1 \mathrm{~mL}$ of stock solution of metformin and teneligliptin and then $1 \mathrm{~mL}$ of $2 \mathrm{~N} \mathrm{NaOH}$ was added and refluxed for 30 $\min$ at $60{ }^{\circ} \mathrm{C}$. The resultant solution was diluted to obtain 500 and $20 \mu \mathrm{g} / \mathrm{mL}$ solution and $10 \mu \mathrm{L}$ were injected into the system and the chromatograms were recorded to assess the stability of the sample.

Peroxide induced degradation: Degradation with peroxide was performed by taking $1 \mathrm{~mL}$ of stock solution of metformin and teneligliptin, $1 \mathrm{~mL}$ of $20 \% \mathrm{H}_{2} \mathrm{O}_{2}$ was added separately. The solutions were kept for $30 \mathrm{~min}$ at $60^{\circ} \mathrm{C}$. For HPLC study, the resultant solution was diluted to obtain 500 and $20 \mu \mathrm{g} / \mathrm{mL}$ solution and $10 \mu \mathrm{L}$ were injected into the system and the chromatograms were recorded to assess the stability of sample.

Neutral degradation: Stress testing under neutral conditions was studied by refluxing the drug in water for $6 \mathrm{~h}$ at $60^{\circ} \mathrm{C}$. For HPLC study, the resultant solution was diluted to 500 and 20 $\mu \mathrm{g} / \mathrm{mL}$ solution and $10 \mu \mathrm{L}$ were injected into the system and the chromatograms were recorded to assess the stability of the sample.

Assessment of validation parameters: As per ICH guidelines, analytical method was known to be validated if it has been evaluated through characteristics such as accuracy, precision, linearity, limit of detection, limit of quantification and robustness. The characteristics of analytical method should be within prescribed limit and defined standards to confirm its accuracy and authenticity [46]. Spiking, mean, standard deviation and relative standard deviation are the terms used to measure the characteristics for a validation of an analytical method.

Accuracy: The accuracy of the method was determined by calculating percentage recovery of metformin and teneligliptin. By applying standard addition method for both the drugs recovery studies have been carried out at three different concentrations such as 50,100,150\% of label claim. At each level ICH recommendation for performing accuracy was minimum triplicate at each concentration and results obtained were compared.

Precision: Precision is the closeness of agreement between series of measurement obtained from multiple sampling of homogenous sample under prescribed conditions. Precision includes repeatability and intra laboratory repeatability; both were performed for six replicates at concentration of 500 and $20 \mu \mathrm{g} / \mathrm{mL}$ metformin and teneligliptin, respectively.

Linearity: Linearity was established from 25 to $150 \%$ of working standard concentration using minimum of six calibration levels $(25,50,75,100,125$ and $150 \%)$ having a range of 125 to $750 \mu \mathrm{g} / \mathrm{ml}$ for metformin and 5 to $30 \mu \mathrm{g} / \mathrm{mL}$ for teneligliptin. The calibration curve was plotted as the concentration of the reference standard of substance against peak area and linearity of the method was evaluated by regression analysis.

LOD and LOQ: The detection limit and the quantification limit of method were obtained from the following formulae:

$$
\begin{aligned}
& \mathrm{LOD}=3.3 \times(\sigma / \mathrm{S}) \\
& \mathrm{LOQ}=10 \times(\sigma / \mathrm{S})
\end{aligned}
$$

where $\sigma=$ standard deviation of response and $S=$ slope obtained from calibration curves of linear study.

Robustness: A few parameters like flow rate, percentage of organic phase and temperature were changed deliberately for the robustness evaluation using HPLC method. One factor was changed at one time to estimate the effect. Each factor selected was changed at three levels $(-1,0,+1)$ with respect to the optimized parameters. Robustness of the method was done at the concentration level 500 and $20 \mu \mathrm{g} / \mathrm{mL}$ metformin and teneligliptin, respectively.

\section{RESULTS AND DISCUSSION}

Optimization of central composite design (CCD): The method optimization was performed by employing design expert software. Three factors and five responses were selected for randomized response surface central composite quadratic design using 20 experimental runs is tabulated in Table-3. Various factors optimized were flow rate, wavelength and $\%$ mobile phase. The limits of these variables were set to yield specific desired numerical conditions for retention time, peak area and resolution. The effects of independent variables on the responses for the 20 experimental runs are summarized in Table-4.

The polynomial equations for the response generated by ANOVA are depicted below:

Retention time $\left(\mathrm{t}_{\mathrm{R}}\right.$ Met $)=+2.88-0.034 * \mathrm{~A}-0.29 * \mathrm{~B}-$ $1.697 \times 10^{-4} * \mathrm{C}+1.250 \times 10^{-3} * \mathrm{AB}-5.000 \times 10^{-4} * \mathrm{AC}+$ $1.500 \times 10^{-3} * \mathrm{BC}+8.301 \times 10^{-3} * \mathrm{~A} 2+0.034 * \mathrm{~B} 2+3.456 \times$ $10^{-4} * \mathrm{C} 2$ 


\begin{tabular}{|c|c|c|c|c|c|c|c|c|}
\hline \multicolumn{9}{|c|}{$\begin{array}{c}\text { TABLE-3 } \\
\text { EXPERIMENTAL FACTORS AND RESPONSES BY USING }\end{array}$} \\
\hline Design point & $\begin{array}{c}\text { Factor } 1 \\
\text { Mobile phase } \\
(\%)\end{array}$ & $\begin{array}{c}\text { Factor } 2 \\
\text { Flow rate } \\
(\mathrm{mL} / \mathrm{min}) \\
\end{array}$ & $\begin{array}{c}\text { Factor } 3 \\
\text { Wavelength } \\
(\mathrm{nm})\end{array}$ & $\begin{array}{c}\text { Response } 1 \\
t_{R}-M e t\end{array}$ & $\begin{array}{l}\text { Response } 2 \\
t_{R}-\text { Ten }\end{array}$ & $\begin{array}{l}\text { Response } 3 \\
\text { Area-Met }\end{array}$ & $\begin{array}{l}\text { Response } 4 \\
\text { Area-Ten }\end{array}$ & $\begin{array}{l}\text { Response } 5 \\
\text { Resolution }\end{array}$ \\
\hline 1 & 40.000 & 1.00000 & 263 & 2.875 & 4.015 & 6018502 & 384475 & 7.4 \\
\hline 2 & 40.000 & 1.00000 & 263 & 2.875 & 4.011 & 5949553 & 380026 & 7.3 \\
\hline 3 & 31.591 & 1.00000 & 263 & 2.952 & 3.614 & 6751604 & 385499 & 3.8 \\
\hline 4 & 40.000 & 1.00000 & 263 & 2.877 & 4.019 & 6053760 & 386393 & 7.4 \\
\hline 5 & 45.000 & 1.10000 & 260 & 2.591 & 4.003 & 10217402 & 223823 & 9.7 \\
\hline 6 & 35.000 & 1.10000 & 260 & 2.663 & 3.414 & 12060824 & 220531 & 4.8 \\
\hline 7 & 40.000 & 1.00000 & 268 & 2.878 & 4.019 & 2100536 & 562896 & 7.4 \\
\hline 8 & 35.000 & 1.10000 & 266 & 2.664 & 3.413 & 3349651 & 445761 & 4.8 \\
\hline 9 & 45.000 & 1.10000 & 266 & 2.594 & 4.006 & 2861088 & 444781 & 9.9 \\
\hline 10 & 40.000 & 1.00000 & 263 & 2.877 & 4.019 & 6053760 & 386393 & 7.4 \\
\hline 11 & 45.000 & 0.90000 & 266 & 3.167 & 4.905 & 3483675 & 532939 & 10.1 \\
\hline 12 & 45.000 & 0.90000 & 260 & 3.174 & 4.902 & 13109937 & 273222 & 10.0 \\
\hline 13 & 48.409 & 1.00000 & 263 & 2.848 & 4.797 & 5271371 & 382674 & 12.2 \\
\hline 14 & 35.000 & 0.90000 & 266 & 3.246 & 4.169 & 4129686 & 547690 & 4.8 \\
\hline 15 & 40.000 & 1.00000 & 263 & 2.875 & 4.015 & 6018502 & 384475 & 7.4 \\
\hline 16 & 40.000 & 0.83182 & 263 & 3.470 & 4.837 & 7508054 & 471719 & 7.2 \\
\hline 17 & 40.000 & 1.16818 & 263 & 2.478 & 3.450 & 5317028 & 341848 & 7.1 \\
\hline 18 & 40.000 & 1.00000 & 258 & 2.877 & 4.019 & 13132296 & 227508 & 7.3 \\
\hline 19 & 40.000 & 1.00000 & 263 & 2.875 & 4.011 & 5949553 & 374541 & 7.3 \\
\hline 20 & 35.000 & 0.90000 & 260 & 3.247 & 4.169 & 14843699 & 269002 & 4.8 \\
\hline
\end{tabular}

TABLE-4

SUMMARY RESULTS FOR RESPONSES IN QUADRATIC MODEL

\begin{tabular}{cccccccc}
\hline Response & Models & Adjusted R & Predicted R & SD & PRESS & CV (\%) & $\begin{array}{c}\text { Adequate } \\
\text { precision }\end{array}$ \\
\hline $\mathrm{t}_{\mathrm{R}}$-Met & Quadratic & 0.9997 & 0.9987 & $4.550 \times 10^{-3}$ & $1.552 \times 10^{-3}$ & 0.16 & 3055.461 \\
$\mathrm{t}_{\mathrm{R}}$ - Ten & Quadratic & 0.9993 & 0.9971 & 0.013 & 0.012 & 0.31 & 169.710 \\
Area-Met & Quadratic & 0.9201 & 0.6819 & $1.045 \times 10^{6}$ & $8.257 \times 10^{13}$ & 14.90 & 18.327 \\
Area-Ten & Quadratic & 0.9602 & 0.8446 & 20475.83 & $3.112 \times 10^{10}$ & 5.37 & 26.344 \\
Resolution & Quadratic & 0.9979 & 0.9924 & 0.10 & 0.68 & 1.35 & 120.545 \\
\hline
\end{tabular}

Retention time $\left(\mathrm{t}_{\mathrm{R}}-\mathrm{Ten}\right)=+4.02+0.34 * \mathrm{~A}-0.41 * \mathrm{~B}$ $+3.661 \times 10^{-4} * \mathrm{C}-0.036 * \mathrm{AB}+8.750 \times 10^{-4} * \mathrm{AC}-1.250 \times$ $10^{-4} * \mathrm{BC}+0.066 * \mathrm{~A} 2+0.044 * \mathrm{~B} 2+2.721 \times 10^{-5} * \mathrm{C} 2$

Peak area $($ Met $)=+5.966 \times 10^{6}-5.273 \times 10^{5} * \mathrm{~A}-7.881 \times$ $10^{5} * \mathrm{~B}-4.024 \times 10^{6} * \mathrm{C}+5973.50 * \mathrm{AB}+3.053 \times 10^{5} * \mathrm{AC}$ $+5.341 \times 10^{5} * \mathrm{BC}+2.729 \times 10^{5} * \mathrm{~A} 2+4.147 \times 10^{5} * \mathrm{~B} 2$ $+8.403 \times 10^{5} * \mathrm{C} 2$

Peak area $($ Ten $)=+3.836 \times 10^{5}-949.71 * \mathrm{~A}-37078.31 *$ $\mathrm{B}+1.134 \times 10^{5} * \mathrm{C}+1605.38 * \mathrm{AB}-2905.37 * \mathrm{AC}-11527.12$ $* \mathrm{BC}-5088.06 * \mathrm{~A} 2+2936.55 * \mathrm{~B} 2-1158.13 * \mathrm{C} 2$

Resolution $=+7.37+2.54 * \mathrm{~A}-0.049 * \mathrm{~B}+0.034 * \mathrm{C}-0.062$ $* \mathrm{AB}+0.038 * \mathrm{AC}+0.013 * \mathrm{BC}+0.19 * \mathrm{~A} 2-0.11 * \mathrm{~B} 2-0.037$ $* \mathrm{C} 2$

The above equations in terms of coded factors can be used to make predictions about the response for given levels of each factor. By default, the high levels of the factors are coded as +1 and the low levels of the factors are coded as -1 . The coded equation is useful for identifying the relative impact of the factors by comparing the factors coefficients.

With the help of design expert software the model was obtained and it was validated by using ANOVA. The results are depicted in Tables 5-7. By using a lack of fit test, the model was examined which indicated a significant lack of fit value corresponding with a lower p-value as compared to the model F-value. From the ANOVA results, the model F-value of teneligliptin and metformin implied that the model was significant.

The perturbation plots are constructed to evaluate the effect of the factors on the retention time, peak area of each drug and resolution. The chromatogram of standard metformin and teneligliptin at optimized conditions obtained by the design is shown in Fig. 1. The optimized conditions includes flow rate

TABLE-5

SUMMARY RESULTS OF ANOVA STATISTICAL ANALYSIS FOR MODELS AND RESPONSE $\left(\mathrm{t}_{\mathrm{R}}\right)$ FOR FINALLY SUGGESTED QUADRATIC MODEL

\begin{tabular}{lcc|cc|cc|cc|cc}
\hline \multirow{2}{*}{ Source } & \multicolumn{2}{c|}{ Sum of squares } & \multicolumn{2}{c|}{ Degree of freedom } & \multicolumn{2}{c|}{ Mean square } & \multicolumn{2}{c|}{ F-Value } & \multicolumn{2}{c}{ P-Value } \\
\cline { 2 - 11 } & Met & Ten & Met & Ten & Met & Ten & Met & Ten & Met & Ten \\
\hline Model & 1.20 & 4.00 & 9 & 9 & 0.13 & 0.44 & 6438.56 & 2816.89 & 0.0001 & 0.0001 \\
Mobile phase & 0.016 & 1.58 & 1 & 1 & 0.016 & 1.58 & 777.64 & 9988.25 & 0.0001 & 0.0001 \\
Flow rate & 1.17 & 2.33 & 1 & 1 & 1.17 & 2.33 & 56315.55 & 14762.51 & 0.0001 & 0.0001 \\
Wavelength & $3.935 \times 10^{-7}$ & $1.831 \times 10^{-6}$ & 1 & 1 & $3.935 \times 10^{-7}$ & $1.831 \times 10^{-6}$ & 0.019 & 0.012 & 0.8931 & 0.9164 \\
Residual & $2.070 \times 10^{-4}$ & $1.579 \times 10^{-3}$ & 10 & 10 & $2.070 \times 10^{-5}$ & $1.579 \times 10^{-4}$ & - & - & - \\
Lack of Fit & $2.017 \times 10^{-4}$ & $1.515 \times 10^{-3}$ & 5 & 5 & $4.034 \times 10^{-5}$ & $3.029 \times 10^{-4}$ & 37.82 & 23.67 & 0.0006 & 0.0017 \\
\hline
\end{tabular}




\begin{tabular}{|c|c|c|c|c|c|c|c|c|c|c|}
\hline \multicolumn{11}{|c|}{$\begin{array}{c}\text { TABLE-6 } \\
\text { STATISTICAL ANALYSIS FOR FACTORS AND RESPONSE (PEAK AREA) BY } \\
\text { ANOVA FOR RESPONSE SURFACE QUADRATIC MODEL }\end{array}$} \\
\hline \multirow{2}{*}{ Source } & \multicolumn{2}{|c|}{ Sum of squares } & \multicolumn{2}{|c|}{$\mathrm{df}$} & \multicolumn{2}{|c|}{ Mean Square } & \multicolumn{2}{|c|}{ F- Value } & \multicolumn{2}{|c|}{ P-Value } \\
\hline & Met & Ten & Met & Ten & Met & Ten & Met & Ten & Met & Ten \\
\hline Model & $2.486 \times 10^{14}$ & $1.961 \times 10^{11}$ & 9 & 9 & $2.763 \times 10^{13}$ & $2.179 \times 10^{10}$ & 25.32 & 51.97 & 0.0001 & 0.0001 \\
\hline Mobile phase & $3.797 \times 10^{12}$ & $1.232 \times 10^{7}$ & 1 & 1 & $3.797 \times 10^{12}$ & $1.232 \times 10^{4}$ & 3.48 & 0.029 & 0.0917 & 0.8673 \\
\hline Flow rate & $8.482 \times 10^{12}$ & $1.878 \times 10^{10}$ & 1 & 1 & $8.482 \times 10^{12}$ & $1.878 \times 10^{10}$ & 7.77 & 44.78 & 0.0192 & 0.0001 \\
\hline Wavelength & $2.212 \times 10^{14}$ & $1.756 \times 10^{11}$ & 1 & 1 & $2.212 \times 10^{14}$ & $1.756 \times 10^{11}$ & 202.72 & 418.86 & 0.0001 & 0.0001 \\
\hline Residual & $1.091 \times 10^{13}$ & $4.193 \times 10^{9}$ & 10 & 10 & $1.091 \times 10^{12}$ & $4.193 \times 10^{8}$ & - & - & - & - \\
\hline Lack of Fit & $1.090 \times 10^{13}$ & $4.085 \times 10^{9}$ & 5 & 5 & $2.180 \times 10^{12}$ & $8.171 \times 10^{8}$ & 969.95 & 38.08 & 0.0001 & 0.0006 \\
\hline
\end{tabular}

\section{STATISTICAL ANALYSIS FOR FACTORS AND RESPONSE (RESOLUTION) BY ANOVA FOR RESPONSE SURFACE QUADRATIC MODEL}

\begin{tabular}{lccccc}
\hline \multicolumn{1}{c}{ Source } & Sum of squares & Degree of freedom & Mean square & F-Value & P-Value \\
\hline Model & 88.69 & 9 & 9.85 & 984.38 & 0.0001 \\
Mobile phase & 87.80 & 1 & 87.80 & 8770.30 & 0.0001 \\
Flow rate & 0.033 & 1 & 0.033 & 3.27 & 0.1009 \\
Wavelength & 0.016 & 1 & 0.016 & 1.60 & 0.2341 \\
Residual & 0.100 & 10 & 0.010 & - & - \\
Lack of Fit & 0.087 & 5 & 0.017 & 0.51 & 0.0303 \\
\hline
\end{tabular}

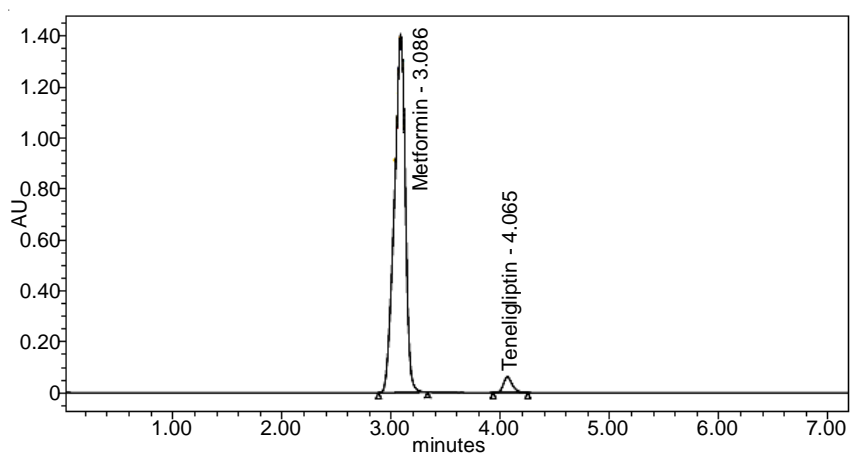

Fig. 1. Chromatogram of drug substance

$0.942 \mathrm{~mL} / \mathrm{min}$, wavelength $261.08 \mathrm{~nm}$ and mixture of acetonitrile and $0.1 \%$ orthophosphoric acid buffer in the ratio of 37: 63 as mobile phase, respectively. The results of system suitability parameters like resolution, plate count, peak area and asymmetric factor were measured to verify optimum conditions and are within the limit. The comparison of initial developed method and optimized method predicted by the design and experimental values are reported in Table-8. The optimized method was validated in compliance with ICH guidelines. Average percentage recoveries for metformin and teneligliptin were found to be 99.99 and $100.44 \%$, respectively, while \% RSD values are less than $1 \%$ indicating accuracy of the repeated method. The calibration curve was found to be linear over the range of $125-750 \mu \mathrm{g} / \mathrm{mL}$ of metformin and 5$30 \mu \mathrm{g} / \mathrm{mL}$ of teneligliptin, respectively (Table-9). As shown in Table-10, the regression analysis of calibration curves and the correlation coefficient for both drugs was found to be 0.999 . The limit of detection and limit of quantification for metformin was found to be 0.06 and $0.08 \mu \mathrm{g} / \mathrm{mL}$ and for teneligliptin 0.19 and $0.25 \mu \mathrm{g} / \mathrm{mL}$, respectively.

The precision data representing both repeatability and intermediate precision are summarized in Table- 10 . The $\%$ RSD values for both repeatability and precision were less than $2 \%$ which indicates that the proposed method is precise. The results for validation and system suitability parameters are

\begin{tabular}{lccc}
\multicolumn{4}{c}{ TABLE-8 } \\
\hline \multirow{3}{*}{ OPTIMIZED METHOD-REPORT CARD } \\
\hline \multirow{2}{*}{ Response variable } & Initial & Optimized method \\
\cline { 3 - 4 } & method & $\begin{array}{c}\text { Predicted by } \\
\text { DE }\end{array}$ & $\begin{array}{c}\text { Experimental } \\
\text { values }\end{array}$ \\
\hline Retention time-Met & 2.884 & 3.07832 & 3.086 \\
Retention time-Ten & 4.030 & 4.07491 & 4.065 \\
Peak Area-Met & 6065677 & 10192910 & 9820218 \\
Peak Area-Ten & 386382 & 326703 & 353678 \\
Resolution & 7.3 & 5.88625 & 5.7 \\
\hline
\end{tabular}

\begin{tabular}{ccc}
\multicolumn{3}{c}{$\begin{array}{c}\text { TABLE-9 } \\
\text { LINEARITY }\end{array}$} \\
\hline $\begin{array}{c}\text { Concentration }(\mu \mathrm{g}) \\
\text { Metformin }\end{array}$ & $\begin{array}{c}\text { Concentration }(\mu \mathrm{g}) \\
\text { Teneligliptin }\end{array}$ & Linearity $(\%)$ \\
\hline 125 & 5 & 25 \\
250 & 10 & 50 \\
375 & 15 & 75 \\
500 & 20 & 100 \\
625 & 25 & 125 \\
750 & 30 & 150 \\
\hline
\end{tabular}

TABLE-10

VALIDATION SUMMARY AND SST PARAMETERS

\begin{tabular}{lcc}
\hline \multicolumn{1}{c}{ Parameter } & Metformin & Teneligliptin \\
\hline Linearity range $(\mu \mathrm{g} / \mathrm{mL})$ & $125-750$ & $25-150$ \\
Correlation coefficient & 0.999 & 0.999 \\
Slope & 18170.3 & 17905 \\
Intercept & 1011 & 773.0 \\
LOD $(\mu \mathrm{g} / \mathrm{mL})$ & 0.06 & 0.08 \\
LOQ $(\mu \mathrm{g} / \mathrm{mL})$ & 0.19 & 0.25 \\
Accuracy $($ Recovery \%) & 99.99 & 100.44 \\
Precision $(\%$ RSD) & & \\
Repeatability & 0.5 & 0.9 \\
Intermediate precision & 1.1 & 1.1 \\
Robustness & Robust & Robust \\
Retention time (min) & 3.086 & 4.065 \\
USP Resolution & - & 5.7 \\
USP Plate Count & 4204 & 12081 \\
Asymmetry factor & 1.0 & 1.3 \\
\hline
\end{tabular}


shown in Table-10. The results for robustness are presented in Table-11, which shows that change in conditions like flow rate, mobile phase ratio and column temperature did not significantly affects the recoveries, peak area and retention time of the drugs indicating that the proposed method was robust. The $\%$ RSD was calculated, which was found to be in permissible limit.

\begin{tabular}{lcc}
\multicolumn{3}{c}{ TABLE-11 } \\
\multicolumn{1}{c}{ RESULTS OF ROBUSTNESS STUDIES } \\
\hline \multicolumn{1}{c}{ Robustness parameter } & $\begin{array}{c}\text { \% RSD for } \\
\text { Metformin }\end{array}$ & $\begin{array}{c}\text { \% RSD for } \\
\text { Teneligliptin }\end{array}$ \\
\hline Flow rate $(0.9 \mathrm{~mL} / \mathrm{min})$ & 0.8 & 1.8 \\
Flow rate $(1 \mathrm{~mL} / \mathrm{min})$ & 0.6 & 0.8 \\
Mobile phase $(58: 42)$ & 0.5 & 0.3 \\
Mobile phase $(68: 32)$ & 1.5 & 1.6 \\
Temperature $\left(25^{\circ} \mathrm{C}\right)$ & 0.3 & 1.2 \\
Temperature $\left(35^{\circ} \mathrm{C}\right)$ & 1.6 & 1.6 \\
\hline
\end{tabular}

Stability studies: The sample was subjected to various stress conditions and the stability of the method was observed. The results of forced degradation studies (Table-12) revealed that the method is stability indicating.

Analysis of marketed formulation: The developed and validated method has been employed for the estimate the teneligliptin and metformin content in a commercially available brand of the tablet containing $20 \mathrm{mg}$ of teneligliptin and $500 \mathrm{mg}$ of metformin (Ten 20-M 500). The potency of the tablet formulation sample was found to be $99.92 \%$ of metformin and $99.97 \%$ teneligliptin, respectively (Table-13) and the system suitability parameters of drug product is shown in Table-14. The amount measured was in good agreement with the label claims. The results of the assay indicated that the method was selective for analysis of teneligliptin and metformin without interference from the excipients (Fig. 2).

TABLE-13

ASSAY RESULTS OBTAINED BY THE PROPOSED METHOD FOR THE DRUGS IN PHARMACEUTICAL PREPARATIONS [Ten 20-M 500 Tablets (LABEL CLAIM $20 \mathrm{mg}$ TEN \& 500 mg MET): $(n=6)]$

\begin{tabular}{lcc}
\hline \multicolumn{1}{c}{ Parameter } & Metformin & Teneligliptin \\
\hline Mean peak area & 9191898 & 352173 \\
Recovery (\%) & 99.92 & 99.97 \\
RSD (\%) & 0.485 & 0.87 \\
\hline
\end{tabular}

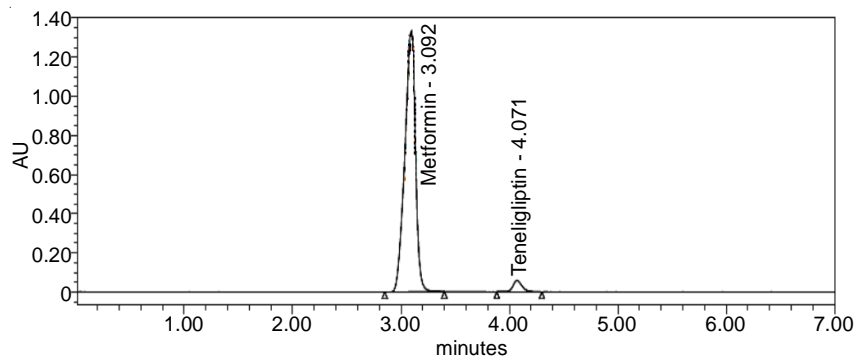

Fig. 2. Chromatogram of drug products

\section{Conclusion}

An innovative, simple, robust QbD approach for RP-HPLC method development has been employed for teneligliptin and metformin. Comparison of experimental results with predicted results illustrated the preciseness of the design. The stability of the developed method was demonstrated by subjecting the drug to various stress conditions. The obtained results revealed that the stability indicating power of the method. Further validation was performed in compliance with ICH guidelines and robustness of the method was verified by varying three chromatographic parameters. The validation results show that the proposed method meets the regulatory aspects. Hence it can be used in the routine quality control analysis of the pharmaceutical formulation.

\section{CONFLICT OF INTEREST}

The authors declare that there is no conflict of interests regarding the publication of this article.

\section{REFERENCES}

1. L.X. Yu, Pharm. Res., 25, 781 (2008); https://doi.org/10.1007/s11095-007-9511-1.

2. N.J. Sangshetti, M. Deshpande, Z. Zaheer, D.B. Shinde and R. Arote, Arab. J. Chem., 10 (Suppl. 2), S3412 (2017); https://doi.org/10.1016/j.arabjc.2014.01.025.

3. K.E. Monks, H.-J. Rieger and I. Molnár, J. Pharm. Biomed. Anal., 56, 874 (2011);

https://doi.org/10.1016/j.jpba.2011.04.015.

4. S. Jain, Int. J. Pharm. Pharm. Sci., 6, 1 (2014).

5. P.K. Sahu, N.R. Ramisetti, T. Cecchi, S. Swain, C.S. Patro and J. Panda, J. Pharm. Biomed. Anal., 147, 590 (2018); https://doi.org/10.1016/j.jpba.2017.05.006.

6. US Food and Drug Administration, Guidance for industry: Q8 Pharmaceutical Development, US Department of Health and Human Service, FDA, Rockville, MD, Nov (2009).

\begin{tabular}{lccc|ccc}
\multicolumn{7}{c}{ TABLE-12 } \\
\multicolumn{1}{c}{ SUMMARY OF FORCED DEGRADATION RESULTS } \\
\hline \multirow{2}{*}{ Stress conditions } & \multicolumn{3}{c}{ Metformin } & \multicolumn{3}{c}{ Teneligliptin } \\
\cline { 2 - 7 } & Degradation (\%) & Purity of angle & Purity of threshold & Degradation (\%) & Purity of angle & Purity of threshold \\
\hline Acid degradation & 3.61697 & 5.745 & 12.651 & 3.06328 & 0.441 & 0.652 \\
Alkali degradation & 4.27139 & 6.697 & 33.597 & 2.10505 & 0.451 & 0.685 \\
Oxidative degradation & 4.00502 & 2.753 & 3.382 & 1.73529 & 0.427 & 0.626 \\
Neutral degradation & 0.95515 & 4.753 & 3.382 & 0.31315 & 0.427 & 0.626 \\
\hline
\end{tabular}

TABLE-14

SYSTEM SUITABILITY PARAMETERS OF DRUG PRODUCT

\begin{tabular}{cccccc}
\hline Peak name & Retention time (min) & Peak area & USP tailing & USP plate count & USP resolution \\
\hline Metformin & 3.092 & 9180013 & 1.07 & 4560 & - \\
Teneligliptin & 4.071 & 357006 & 1.26 & 12216 & 5.7 \\
\hline
\end{tabular}


7. US Food and Drug Administration, Guidance for Industry: Q9 Quality Risk Management, US Department of Health and Human Service, FDA, Rockville, MD, June (2006)

8. US Food and Drug Administration, Guidance for Industry: Q10 Quality Systems Approach to Pharmaceutical cGMP Regulations, FDA, Rockville, MD, April (2009).

9. ICH Harmonized Tripartite Guideline on Pharmaceutical Quality Systems Q10, step 4 version, June (2008).

10. D. Bhatt and S. Rane, Int. J. Pharm. Pharm. Sci., 3, 1 (2011).

11. I. Hameed, S.R. Masoodi, S.A. Mir, M. Nabi, K. Ghazanfar and B.A. Ganai, World J. Diabetes, 6, 598 (2015). https://doi.org/10.4239/wjd.v6.i4.598.

12. A. Shahi, V.S.S. Prasad, S.S. Imam, A. Muheem and M.A. Jahangir, Asian J. Biomed. Pharm. Sci., 8, 28 (2018); https://doi.org/10.4066/2249-622X.65.18-845.

13. M.H. Rahman and M.Y. Ali, Faridpur Med. Coll. J., 10, 36 (2015).

14. H.W. Baynes, J. Diabetes Metab., 6, 541 (2015); https://doi.org/10.4172/2155-6156.1000541.

15. Y. Shi and F.B. Hu, Lancet, 383, 1947 (2014); https://doi.org/10.1016/S0140-6736(14)60886-2.

16. M. Maladkar, S. Sankar and K. Kamat, J. Diabetes Mellitus, 6, 113 (2016); https://doi.org/10.4236/jdm.2016.62012.

17. M. Kishimoto, Diabetes Metab. Syndr. Obes., 6, 187 (2013); https://doi.org/10.2147/DMSO.S35682.

18. https://www.drugbank.ca/drugs/DB11950- Teneligliptin- drug bank.

19. https://www.drugbank.ca/drugs/DB00331- Metformin- drug bank.

20. A.M. Sonawane, K.K. Dhokale and V.A. Randhe, Indo Am. J. Pharm. Res., 6, 5219 (2016).

21. T.N.V. Ganesh Kumar, S. Vidyadhara, N.A. Narkhede, Y.S. Silpa and M.R. Lakshmi, J. Anal. Sci. Technol., 7, 18 (2016); https://doi.org/10.1186/s40543-016-0099-0.

22. S.S. Chitlange, D.G. Rawat and S. Chandani, Indo Am. J. Pharm. Res., 6, 6144 (2016)

23. C.V. Shinde, K.B. Aher, G.B. Bhavar, S.J. Kakad and S.R. Chaudhari, Der Pharm. Lett., 8, 8 (2016).

24. Indian Pharmacopoeia, Government of India, Ghaziabad, The Indian Pharmacopoeia Commission, vol. 2, p. 1358 (2007).

25. British Pharmacopoeia, Her Majesty's Stationary Office: London, UK, vol. 1 and 2, p. 3813 (2009).

26. European Pharmacopoeia, Council of Europe, France 55 and United States Pharmacopoeia BP (The United States Pharmacopoeia), edn 3 (1997)

27. The United States Pharmacopoeia, US Pharmacopoeial Convention, Inc.: Rockville, MD. 31st Revision. p. 2640 (2008).
28. United States Pharmacopoeia and National Formulary USP 24-NF 19; the United States Pharmacopoeial Convention, Inc.: Rockville, MD (2000).

29. P. Madhusudhan, M.R. Reddy and N. Devanna, Der Pharm. Lett., 7, 3 (2015).

30. T.S. Nipun, D. Debnath, M.S.U.H. Miah, M.K. Hossain and S.M.M. Hossen, Int. J. Pharm. Sci. Res., 8, 8 (2017); https://doi.org/10.7897/2230-8407.08012.

31. B.R. Jani, K.V. Shah and P.P. Kapupara, Int. J. Res. Develop. Pharm. Life Sci., 4, 3 (2015).

32. G. Nirupa and U.M. Tripathi, J. Chem., Article ID 402723 (2013); https://doi.org/10.1155/2013/402723.

33. S.K. Karimulla, P.M. Vasanth, T. Ramesh and M. Ramesh, Der Pharm. Lett., 5, 5 (2013).

34. S. Caglar and A.R. Alp, J. Anal. Bioanal. Technol., S12, 10 (2014).

35. N. Sirigiri and S.N. Siva, Der Pharm. Chem., 9, 21 (2017).

36. P. Gayathri and K.N. Jayaveera, World J. Pharm. Pharm. Sci., 4, 4 (2015).

37. B. Surendra babu, K.S.Nataraj, A.K.M. Pawar, K. Gnananath, Int. J. Pharma Bio Sci., 8, 4 (2017).

38. A.K. Sen, D.N. Hinsu, D.B. Sen, A.S. Zanwar, R.A. Maheshwari and V.R. Chandrakar, J. Appl. Pharm. Sci., 6, 9 (2016).

39. V.M. Shastry, T. Mujawar and L. Thakare, J. Pharm. Res., 11, 676 (2017).

40. M.D. Patil, M. Bapna, P. Shah and S.S. Khoja, J. Pharm. Sci. Bioscient. Res., 7, 2 (2017).

41. G.S. Irache, N.S. Bhajipale and L.R. Gandhi, Int. Res. J. Pharm., 8, 52 (2017); https://doi.org/10.7897/2230-8407.088144.

42. M. Blessy, R.D. Patel, P.N. Prajapati and Y.K. Agrawal, J. Pharm. Anal., 4, 159 (2014); https://doi.org/10.1016/j.jpha.2013.09.003.

43. R.M. Maggio, S.E. Vignaduzzo and T.S. Kaufman, TrAC Trends Analyt. Chem., 49, 57 (2013); https://doi.org/10.1016/j.trac.2013.05.008.

44. M. Bakshi and S. Singh, J. Pharm. Biomed. Anal., 28, 1011 (2002); https://doi.org/10.1016/S0731-7085(02)00047-X.

45. International Conference on the Harmonisation, ICH Harmonized Tripartite Guideline. Stability Testing of New Drug Substances and Products Q1A (R2), November (2003).

46. International Conference on the Harmonization of Technical Requirements for Registration of Pharmaceuticals for Human Use. ICH Harmonized Tripartite Guideline, Validation of Analytical Procedures: Text and Methodology Q2 (R1), November (2005). 